\title{
PERBANDINGAN HISTORICAL COST DAN CURRENT COST SEBAGAI DASAR PENILAIAN ZAKAT PERBANKAN SYARIAH
}

\author{
Any Eliza dan Rahmat Fajar Ramdani \\ Universitas Islam Negeri Raden Intan Lampung \\ Jl. Letnan Kolonel H. Endro Suratmin, Sukarame, Kota Bandar Lampung, 35131 \\ Email: anyeliza@radenintan.ac.id dan rahmatfajar@radenintan.ac.id
}

\begin{abstract}
This research aims to count and analyze the income of Sharia Commercial Bank based on current cost measurement and also test statistically the significancy of differences between the two measurements basis (historical cost and current cost). This research uses financial statements for the year 2018 of 12 Sharia Commercial Banks. The data is collected by using documentation method and literature study method. Analysis of data is conducted by using descriptive analysis and paired t-test to answer the hypothesis proposed in this research. Findings from the reserach shows that generally, income before zakah and tax of 12 Sharia Commercial Banks counted by using current cost measurement is higher than income before zakah and tax counted by using historical cost measurement. Although the result is not significant statistically, the differences are valuable and can affect the sum of zakat should be paid.
\end{abstract}

Keywords: historical cost, current cost, zakat, sharia commercial banks

\begin{abstract}
ABSTRAK
Penelitian ini bertujuan untuk menghitung dan menganalisis laba Bank Umum Syariah di Indonesia dengan menggunakan dasar pengukuran current cost serta menguji secara statistik apakah terdapat perbedaan signifikan antara laba yang dihitung berdasarkan dasar pengukuran historical cost dengan current cost. Penelitian ini menggunakan data laporan keuangan konsolidasian 12 Bank Umum Syariah tahun 2018. Metode pengumpulan data yang digunakan adalah metode dokumentasi dan studi pustaka. Analisis data dilakukan dengan analisis deskriptif serta uji statistik berupa uji t dua sampel berpasangan (paired t-test) untuk membuktikan hipotesis yang diajukan dalam penelitian ini. Hasil penelitian menunjukkan bahwa dasar pengukuran current cost menghasilkan nilai laba sebelum zakat dan pajak yang lebih tinggi dibandingkan dasar pengukuran historical cost. Meskipun hasilnya tidak signifikan secara statistik, perbedaannya sangat berharga dan dapat mempengaruhi jumlah zakat yang harus dibayar
\end{abstract}

Kata kunci: historical cost, current cost, zakat, Bank Umum Syariah 


\section{PENDAHULUAN}

Akuntansi memainkan peranan yang sangat penting bagi perhitungan zakat perusahaan. Melalui output atau proses akuntansi berupa laporan keuangan perusahaan, maka diperoleh informasi yang nantinya dijadikan dasar untuk menghitung kewajiban zakat. Akuntansi berkontribusi dalam proses perhitungan zakat yang tepat, seperti zakat maal, zakat penghasilan, zakat profesi, zakat perdagangan, zakat laba, dan sebagainya. Syafei (2008) sebagaimana dikutip Wasilah (2013) menyatakan bahwa zakat perusahaan didasarkan pada prinsip keadilan dan hasil dari ijtihad para ahli fikih sehingga jenis zakat tersebut relatif sulit ditemukan di kitab fikih klasik. Zakat perusahaan oleh para ulama kontemporer dianalogikan dengan zakat perdagangan, dimana kegiatan utamanya adalah kegiatan trading atau perdagangan.

Pengungkapan zakat yang harus dibayarkan oleh perusahaan merupakan tujuan dari akuntansi syariah (Gambling \& Karim, 1991). Hal tersebut selaras dengan pernyataan YAYA (2003) bahwa prinsip pertanggungjawaban adalah hal yang sangat penting dalam akuntansi. Sementara dalam ruang lingkup akuntansi Islam, pengungkapan zakat menjadi tujuan utama. Pengungkapan zakat tidak ditemukan dalam domain akuntansi konvensional. Dalam akuntansi Islam, informasi akuntansi yang disajikan untuk para pemangku kepentingan menjadi lebih luas karena tidak hanya mencakup data keuangan berupa laporan keuangan, tetapi juga mencakup informasi tentang aktivitas atau kegiatan perusahaan yang tidak bertentangan dengan ketentuan syariah serta pembayaran zakat. Mengingat informasi dalam laporan keuangan sangat diperlukan untuk mengakomodasi kebutuhan perhitungan zakat perusahaan, maka hal selanjutnya yang perlu diperhatikan adalah apa dasar pengukuran yang akan digunakan untuk menilai aset yang akan menjadi subjek zakat: historical cost atau current cost.

Dasar pengukuran unsur laporan keuangan yang pada umumnya digunakan oleh perusahaan adalah biaya perolehan (historical cost). Jika dasar pengukuran biaya perolehan (historical cost) digunakan, maka aset akan dicatat sebesar kas atau setara kas yang dibayarkan atau sebesar nilai wajar dari imbalan untuk memperoleh aset tersebut pada saat perolehan; sementara kewajiban dicatat sebesar jumlah yang diterima sebagai penukar dari kewajiban (Dewan Standar Akuntansi Syariah IAI, 2016). Dasar pengukuran Biaya perolehan (historical cost) mudah untuk diterapkan karena dapat diverifikasi/teruji dan bersifat objektif berdasarkan saat perolehannya. Pengukuran dengan metode ini juga memberikan informasi yang bemanfaat untuk memprediksi masa depan bagi para pengambil keputusan seperti para manajer dan investor (Harahap, 2011). Oleh karena itu, pengukuran dengan biaya perolehan (historical cost) masih diperkenankan oleh standar akuntansi keuangan yang berlaku saat ini.

Namun demikian, banyak kritik diberikan atas konsep pengukuran menggunakan biaya perolehan ini terkait dengan adanya perubahan dalam kemampuan daya beli dan perubahan harga. Biaya perolehan (historical cost) 
mengasumsikan bahwa daya beli uang atau unit moneter bersifat stabil sehingga perubahan nilai dalam unit moneter adalah tidak material (Suwardjono, 2011). Lebih lanjut Harahap (2011) menambahkan bahwa stable monetary unit kenyataannya tidak ada. Tingkat inflasi setiap negara berbeda-beda dan tidak ada satupun negara di dunia ini yang memiliki nilai valuta stabil. Dengan demikian, inflasi berdampak terhadap relevansi penyajian laporan keuangan.

Pengukuran aset dan liabilitas yang menjadi dasar penentuan besaran zakat perusahaan dalam perspektif Islam lebih ditekankan pada penggunaan pengukuran nilai wajar (fair value) dibandingkan historical cost. Hal tersebut dikarenakan pengukuran fair value dapat menghasilkan informasi yang sesuai dengan kondisi saat ini (Pratiwi \& Siswantoro, 2018). Pengukuran aset terkait perhitungan zakat merupakan hal penting dalam perspektif Islam serta merekomendasikan penilaian ulang (re-value) aset secara teratur; sistem akuntansi Islam pada umumnya menggunakan harga jual pasar (market selling prices) dan biaya historis untuk mengakomodasi kontrak transaksi dan pelaksanaan tanggung jawab sosial (Mirza \& Baydoun, 2000). Jika dasar pengukuran current cost digunakan, maka zakat dihitung berdasarkan nilai kini dari aset yang dimiliki. Hal ini sesuai dengan hadist Nabi Muhammad SAW: "measure based on the price today, then pay zakat", sebagaimana dikutip oleh Pratiwi \& Siswantoro (2018).

Hasil penelitian Awang \& Mokhtar (2012) tentang penilaian zakat perusahaan di Malaysia dengan menggunakan dasar pengukuran current value dan historical cost menunjukkan bahwa penggunaan dasar pengukuran current value menghasilkan zakat yang lebih tinggi dibandingkan dengan penggunaan dasar pengukuran historical cost. Hasil ini mendukung hipotesis sebelumnya yang menyatakan bahwa dasar pengukuran historical cost kurang tepat untuk dasar penilaian zakat, terutama dalam kondisi inflasi.

Hasil penelitian Pratiwi \& Siswantoro (2018) menunjukkan bahwa dari 15 perusahaan yang terdaftar di Jakarta Islamic Index (JII), hanya sembilan perusahaan yang menggunakan fair value sebagai dasar pengukuran beberapa aset dan liabilitasnya. Penggunaan fair values sebagai dasar pengukuran aset dan liabilitas penting bagi perusahaan untuk menghitung zakat perusahaan. Sementara enam perusahaan lainnya menggunakan historical cost sebagai dasar pengukuran aset dan liabilitas.

Dasar pertimbangan penerapan dasar pengukuran historical cost adalah adanya anggapan bahwa tingginya nuansa judgement, terutama pada aset tertentu yang tidak memiliki pasar dan adanya tambahan biaya dalam rangka melakukan appraisal atas aset yang perusahaan miliki untuk dapat disajikan menggunakan current cost. Sementara di sisi lain, entitas syariah harus membayar zakat serta menyusun dan memublikasikan Laporan Sumber dan Penyaluran Dana Zakat sebagaimana diatur dalam PSAK No. 101 tentang Penyajian Laporan Keuangan Syariah. Dengan demikian, dasar pengukuran unsur laporan keuangan menjadi sangat penting karena terkait dengan penilaian zakat perusahaan.

Penelitian ini bertujuan untuk menganalisis perbedaan perhitungan laba bersih Bank Umum Syariah di Indonesia dengan menggunakan dasar 
pengukuran histrorical cost dan current cost pada unsur-unsur dalam laporan keuangannya. Perbedaan dasar pengukuran unsur-unsur dalam laporan keuangan berimplikasi pada perbedaan laba perusahaan. Perbedaan tersebut dapat mempengaruhi nilai ekuitas dan current asset yang pada akhirnya menghasilkan perbedaan besaran zakat yang akan dibayar oleh bank syariah.

\section{TELAAH TEORITIS DAN PENGEMBANGAN HIPOTESIS}

\subsection{AKUNTANSI SYARIAH DAN ZAKAT PERUSAHAAN}

Akuntansi syariah dapat didefinisikan sebagai proses akuntansi yang berfungsi untuk menghasilkan informasi yang tidak terbatas pada data keuangan, saja, tetapi juga informasi tentang aktivitas entitas yang berjalan sesuai dengan hukum-hukum Islam (ketentuan syariah) serta memiliki tujuan sosial yang tidak terhindarkan dalam Islam, seperti adanya kewajiban untuk membayar zakat (Wasilah, 2013). Harahap (1997) sebagaimana dikutip Triyuwono (2012) menyatakan bahwa pengungkapan tentang kebenaran, keadilan, kepastian, keterbukaan, dan akuntabilitas atas transaksi yang telah dilakukan oleh perusahaan merupakan tujuan dari akuntansi syariah. Selain tujuan di atas, akuntansi syariah lebih berorientasi pada pengungkapan zakat yang wajib dikeluarkan oleh perusahaan. Oleh karena itu, akuntansi memainkan peranan yang sangat penting untuk menghasilkan informasi yang nantinya dijadikan dasar untuk menghitung kewajiban zakat.

Tiga prinsip utama dalam akuntansi syariah adalah: (1) Prinsip pertanggungjawaban, dimana prinsip ini terkait dengan konsep amanah yang berarti bahwa manajemen perusahaan harus mampu mengamalkan ketentuan syariah dalam menjalankan aktivitas bisnisnya; (2) Prinsip keadilan, yang dalam konteks akuntansi berarti bahwa setiap transaksi yang dilakukan oleh perusahaan harus dicatat dengan benar, tanpa adanya window dressing sehingga tidak merugikan pihak lain; (3) Prinsip kebenaran, dimana prinsip ini dapat menciptakan keadilan dalam mengakui, mengukur, dan melaporkan transaksi-transaksi (Muhammad, 2005).

Muhammad (2003) menyebutkan bahwa paradigma dalam akuntansi syariah tidak hanya fokus pada peran akuntansi dalam penyediaan informasi ekonomi,dasar pengambilan keputusan, serta pelaporan pendapatan secara tepat, tetapi juga menunjukkan adanya perbedaan ideologi akuntasi, dimana pijakan utama dalam akuntansi syariah adalah: 1) mencari keridhoan Allah SWT, hal ini menjadi tujuan utama untuk mencapai keadilan sosio-ekonomi; 2) merealisasikan keuntungan bagi masyarakat, dengan cara memenuhi kewajiban kepada masyarakat; 3) mengejar kepentingan pribadi, dengan memenuhi kebutuhan diri sendiri. Pelaksanaan tiga aktivitas tersebut merupakan bagian dari ibadah dan sebagai bentuk pemenuhan kewajiban kepada Tuhan, masyarakat, serta hak individu.

Lebih lanjut Muhammad (2003) menyatakan bahwa tujuan utama akuntansi syariah adalah untuk menciptakan keadilan sosio-ekonomi (alfalah), yang diturunkan ke dalam aspek teknis maupun kemanusiaan. Dalam 
akuntansi syariah, aspek teknis merujuk kepada konstruk akuntansi yang terkait dengan otoritas dan pelaksanaannya. Sementara konstruk terkait dengan pengukuran dan pengungkapan, serta prinsip-prinsip zakat, bebas bunga, transaksi bisnis yang diperbolehkan menurut ketentuan hukum Islam. Konstruk akuntansi yang terkait dengan otoritas maupun pelaksananya didasarkan pada pemenuhan prinsip taqwa, pertanggungjawaban, serta kebenaran. Dengan demikian, perbedaan antara akuntansi konvensional dengan akuntansi syariah tidak hanya terletak pada batasan tujuan, tetap juga terletak pada prinsip-prinsip dasarnya.

Zakat perusahaan merupakan zakat yang dikeluarkan oleh sebuah usaha yang dikelola sebagai sebuah kesatuan resmi; setiap perusahaan yang bergerak di bidang produksi (hasil industri/pabrikasi) dan jasa dapat menjadi wajib zakat (Mufraini, 2006). Manaf menyebutkan bahwa zakat tersebut dikeluarkan jika telah memenuhi beberapa persyaratan berikut (Wasilah, 2013):

1. Muslim sebagai pemilik mayoritas usaha

2. Jenis usaha halal

3. Aset/kekayaan perusahaan dapat dinilai

4. Aset/kekayaan perusahaan dapat berkembang

5. Aset/kekayaan minimal perusahaan setara dengan 85 gram emas

Nisab dan persentase zakat perusahaan yaitu senilai nisab emas dan perak 85 gram emas dan telah cukuphaul (1 tahun qomariah). Sementarapersentase besaran zakat adalah 2,5\% dari aset wajib zakat yang dimiliki perusahaan.

\subsection{METODE PERHITUNGAN ZAKAT PERUSAHAAN}

Metode perhitungan zakat perusahaan menurut pendapat para ulama adalah sebagai berikut (Syafei, 2008):

1. Menurut pendapat Qardhawi, zakat dikenakan atas aset/kekayaan perusahaan yang dipergunakan dalam rangka memperoleh laba. Zakat dikenakan atas aset lancar bersih (net current asset) sehingga zakat = current asset - current liabilities

2. Menurut pendapat El Badawi dan Sultan, zakat dikenakan atas pertumbuhan modal bersih, dengan kata lain zakat tidak dikenakan atas aset tetap, tetapi atas aset yang tumbuh atau berkembang (growing capital).

3. Menurut Lembaga Fatwa Arab Saudi, zakat dikenakan atas kekayaan bersih perusahaan.

Berdasarkan hasil studi kasus yang dilakukan oleh Awang \& Mokhtar (2012) di Pusat Zakat Selangor (PZS), terdapat 2 pendekatan perhitungan zakat yang umumnya berlaku di Malaysia, yaitu Growth Model (Urfiyyah) dan Working Capital Model (Syarr"iyyah). Berdasarkan pendekatan working 
capital, maka perusahaan wajib membayar zakat tanpa melihat apakah perusahaan memperoleh laba bersih atau tidak. Selama perusahaan memiliki modal kerja (working capital) bersih atau dengan kata lain perusahaan memiliki surplus assets dan sudah memenuhi nisab serta haul, maka perusahaan wajib membayar zakat. Sementara AAOIFI (1998) melalui (FAS) Financial Accounting Standard No 9 sebagaimana dikutip oleh Wasilah (2013) menyatakan dua metode perhitungan zakat perusahaan: pendekatan aset bersih (net assets method) dan pendekatan dana investasi (invested fund method).

Dua metode perhitungaan zakat yang pada umumnya dipraktikkan di Indonesia, yaitu (Farhan \& Triyuwono, 2012):

1. Zakat Perusahaan $=2,5 \% \mathrm{x}$ laba bersih setelah pajak

2. Zakat Perusahaan $=2,5 \% \times$ (Aset lancar - Utang lancar $)$

\subsection{CURRENT COST SEBAGAI DASAR PENGUKURAN ZAKAT PERUSAHAAN}

Dewan Standar Akuntansi Syariah IAI (2016) melalui Kerangka Dasar Penyusunan dan Penyajian Laporan Keuangan Syariah menyebutkan bahwa unsur-unsur penyusun laporan keuangan terdiri atas aset, liabilitas/kewajiban, dana syirkah temporer, ekuitas, penghasilan, beban, serta hak pihak ketiga atas bagi hasil dana syirkah temporer. Selain itu, terdapat pula komponen zakat dan dana kebajikan sebagai unsur laporan keuangan yang mencerminkan kegiatan sosial. Dasar pengukuran dari unsur-unsur laporan keuangan mencakup biaya perolehan (historical cost), biaya kini (current cost), nilai realisasi (realizable/settlement value).

Jika dasar pengukuran biaya perolehan (historical cost) digunakan, maka aset dicatat sebesar pengeluaran kas (atau setara kas) yang dibayar atau sebesar nilai wajar dari imbalan (consideration) yang diberikan untuk memperoleh aset tersebut pada saat perolehan. Kewajiban dicatat sebesar jumlah yang diterima sebagai penukar dari kewajiban (obligation), atau dalam keadaan tertentu (misalnya, pajak penghasilan), dalam jumlah kas (atau setara kas) yang diharapkan akan dibayarkan untuk memenuhi kewajiban dalam pelaksanaan usaha yang normal (Dewan Standar Akuntansi Syariah IAI, 2016). Biaya perolehan (historical cost) merupakan dasar pengukuran yang umumnya digunakan oleh sebagian besar perusahaan, termasuk entitas syariah dalam penyusunan laporan keuangannya. Alasan penggunaan dasar pengukuran ini adalah biaya perolehan (historical cost) mudah untuk diterapkan karena dapat diverifikasi dan bersifat objektif berdasarkan saat perolehannya Pada saat laporan keuangan disusun menggunakan dasar pengukuran biaya perolehan, maka nilai yang digunakan adalah harga pada saat transaksi dan sebagai alat ukurnya digunakan satuan unit moneter.

Sementara jika dasar pengukuran biaya kini (current cost) digunakan, maka aset dinilai dalam jumlah kas (atau setara kas) yang seharusnya dibayar bila aset yang sama atau setara aset diperoleh sekarang. Kewajiban dinyatakan dalam jumlah kas (atau setara kas) yang tidak didiskontokan (undiscounted) yang mungkin akan diperlukan untuk menyelesaikan 
kewajiban (obligation) sekarang (Dewan Standar Akuntansi Syariah IAI, 2016). Menurut dasar pengukuran ini, aset akan diakui sebesar nilai kini sehingga aset yang ada harus direvaluasi setiap periode. Nilainya akan berfluktuasi sesuai dengan kondisi pada periode pelaporan. Jika terjadi inflasi, maka nilai aset akan disesuaikan dengan keadaan tersebut. Hal ini menjadikan kualitas informasi laporan keuangan mencerminkan keadaan yang sebenarnya dan informasi menjadi lebih relevan dibandingkan dengan informasi yang dihasilkan dengan dasar pengukuran biaya perolehan.

Gambling dan Karim, Hamid, dan Sulaiman sebagaimana dikutip oleh (Wasilah, 2013) menyarankan penggunaan nilai kini (current value) dibandingkan biaya perolehan (historical value), terutamadalam rangka perhitungan harta yang akan dikenakan zakat. Hal serupa diperkuat oleh Qardhawi (2004) yang berpendapat bahwa penilaian zakat harus didasarkan pada saat zakat akan dikeluarkan. Dengan demikian, entitas syariah perlu mengadopsi model penilaian aset kena zakat yang selaras dengan prinsip syariah. Dengan kata lain, kebijakan akuntansi terkait zakat yang diadopsi sangat berbeda dengan kebijakan akuntansi yang diadopsi perusahaan pada umumnya yang ditujukan untuk meminimalisir pajak (Ahmed, Bin Aiffin, Yousif Alabdullah, \& Zuqebah, 2016).

Berdasarkan pemaparan di atas dapat disimpulkan bahwa sebelum dikeluarkan zakatnya, harta wajib zakat harus dinilai ulang dengan harga pasar yang berlaku pada saat akan dikeluarkan zakatnya (current cost). Penggunaan current cost accounting sebagai dasar pengukuran unsurlaporan keuangan pada entitas syariah merupakan salah satu bentuk perluasan akuntabilitas/pertanggungjawaban perusahaan di ranah sosial serta dianggap memenuhi prinsip-prinsip keadilan Islam, terutama dalam menentukan zakat daripada penggunaan historical cost dalam neraca (Hartono, 2016).

Penggunaan dasar pengukuran yang berbeda pada unsur-unsur dalam laporan keuangan dapat berimplikasi pada perbedaan laba perusahaan. Perbedaan tersebut dapat mempengaruhi nilai ekuitas dan current asset yang pada akhirnya menghasilkan perbedaan besaran zakat yang akan dibayar oleh bank syariah. Untuk itu, peneliti mengajukan hipotesis sebagai berikut:

$H_{o}$ : Tidak terdapat perbedaan signifikan antara lababerdasarkan current cost accounting dengan laba berdasarkan historical cost accounting

$H_{a}$ : Terdapat perbedaan signifikan antara laba menggunakan current cost accounting dengan laba berdasarkan historical cost accounting

\section{METODE PENELITIAN}

Penelitian ini menggunakan metode pendekatan penelitian secara kuantitatif dengan menggunakan alat analisis statistik untuk menguji hipotesis yang diajukan. Jenis data yang digunakan dalam penelitian ini adalah data sekunder berupa laporan keuangan konsolidasian dari 12 Bank Umum Syariah tahun 2018 yang bersumber dari: 
1. website resmi Bursa Efek Indonesia, yaitu https://www.idx.co.id/perusahaan-tercatat/laporan-keuangan-dantahunan/

2. website resmi Bank Umum Syariah yang menjadi sampel dalam penelitian ini.

Populasi dalam penelitian ini adalah seluruh Bank Umum Syariah yang memublikasikan laporan keuangan tahun 2018, yaitu sejumlah 14 bank. Berdasarkan teknik purposive sampling, terpilih 12 Bank Umum Syariah dengan kriteria: (1) Bank yang menggunakan dasar pengukuran biaya perolehan (historical cost) pada sebagian dan atau seluruh unsur-unsur dalam laporan keuangannya; (2) nilai buku aset tetap tidak sama dengan nol.

Data dikumpulkan dengan menggunakan metode: (1) dokumentasi, yaitu bersumber dari dokumentasi laporan keuangan konsolidasian Bank Umum Syariah untuk periode 31 Desember 2018; (2) Studi pustaka, yaitu dengan mengumpulkan informasi dari berbagai literatur seperti buku, jurnal, hasil penelitian, artikel, dan sumber lainnya yang relevan dengan tema penelitian ini.

Metode analisis data dalam penelitian ini yaitu:

1. Analisis statistika deskriptif, dilakukan untuk memperoleh gambaran tentang perbedaan laba bank syariah berdasarkan penggunaan pengukuran historical cost dan current cost yang diperoleh masing masing bank serta untuk mengetahui bank yang memiliki laba tertinggi dan juga terendah, melalui tampilan grafik maupun tabulasi.

Sebelum dilakukan perbandingan, maka akan dilakukan terlebih dahulu tahapan perhitungan profit nominal dari laporan keuangan Bank Umum Syariah menggunakan metode current cost accounting yang diadopsi dari Hameed (2000) sebagaimana dikutip oleh Sidik \& Djazuli (2010) dengan beberapa penyesuaian dapat dilihat pada ilustrasi berikut:

PT ABC

Profit nominal

$x x x$

Adjustment depreciation

$\underline{x x x}$

Adjustment profit

$x x x$

Fixed asset used

$\underline{(x x x)}$

Profit CVA

$x x x$

Berdasarkan perhitungan di atas, profit atau laba yang dihasilkan oleh perusahaan akan berpengaruh terhadap current aset sehingga profit yang ada harus disesuaikan dengan menggunakan metode current cost accounting dan beberapa penyesuaian. Tahapan-tahapan tersebut adalah sebagai berikut:

a. profit nominal atau dalam laporan laba rugi komprehensif disebut sebagai laba sebelum zakat dan pajak penghasilan; 
b. beban depresiasi yang telah dikurangkan pada laporan laba rugi harus ditambahkan karena pembebanan depresiasi dinilai berdasarkan historical cost accounting sehingga perlu disesuaikan;

c. sebagai konsekuensi dari penambahan beban depresiasi, maka profit yang telah disesuaikan dikurangi dengan penggunaan fixed asset dengan menggunakan current cost accounting (sebagai ganti beban depresiasi).

Penggunaan aset tetap (fixed asset) akan dihitung berdasarkan current cost accounting. Oleh karena itu, akan digunakan Indeks Harga Konsumen (Consumer Price Inde Index) sebagai faktor konversi akibat adanya inflasi sebagaiman diadopsi dari penelitian Sidik \& Djazuli (2010):

Penggunaan Fixed Asset $=\sum_{i=0}^{n}\left(\frac{C P I_{n}}{C P I_{n-1}} \times F A_{n}\right)-\sum_{i=0}^{n} F A_{n}$

$\mathrm{FA}=$ Fixed Asset (aset tetap)

$\mathrm{CPI}=$ Consumer Price Index

$\mathrm{n} \quad=$ tahun yang akan diuji (dalam hal ini adalah 2018)

$\mathrm{i} \quad=$ tahun yang dijadikan patokan dimulai dari tahun pembelian aset. Dalam hal ini, pembelian aset diasumsikan tahun 2017.

Jika terdapat kelompok aset tetap tertentu menggunakan metode revaluasi sebagai dasar pengukuran setelah pengakuan awal, maka kelompok aset tetap tersebut dikurangkan dari nilai total aset tetap tahun berjalan, selisihnya (aset yang dinilai menggunakan dasar historical cost) perlu disesuaikan dengan memperhitungkan inflasi tahun berjalan.

Uji t untuk dua sampel berpasangan (paired t-test), dilakukan dengan cara membandingkan perbedaan antara dua nilai rata-rata dengan standar error dari perbedaan rata-rata dua sampel (Ghozali, 2006). Uji statistik ini digunakan untuk menjawab hipotesis yang diajukan dalam penelitian ini. Dalam kaitannya dengan penelitian ini, sampel terdiri dari 12 Bank Umum Syariah yang telah mempublikasikan laporan keuangan untuk tahun 2018, namun mendapat perlakuan yang berbeda karena akan dilakukan perbandingan penilaian aset pada perusahaan tersebut dengan menggunakan metode current cost accounting dan historical cost accounting. Metode penilaian yang berbeda akan menghasilkan laba yang berbeda sehingga akan berpengaruh terhadap ekuitas; selisihnya akan dialokasikan ke current asset. Hal tersebut akan berdampak terhadap besarnya aset (harta) kena zakat. 


\section{ANALISIS DATA DAN PEMBAHASAN}

\subsection{ANALISIS STATISTIKA DESKRIPTIF}

Analisis statistika deskriptif pada penelitian ini dilakukan untuk mengetahui perbedaan besaran laba yang diperoleh 12 Bank Umum Syariah di Indonesia yang terpilih sebagai sampel, dengan menggunakan dasar pengukuran historical cost dan current cost. Selain itu, melalui analisis ini juga dapat diketahui bank yang menghasilkan laba tertinggi dan juga yang terendah selama periode tahun 2018.

Tabel 1. Perbandingan Laba Menggunakan Dasar Pengukuran Historical Cost dan Current Cost Pada Bank Umum Syariah di Indonesia Tahun 2018

(dalam juta rupiah)

\begin{tabular}{rlrrrrrr}
\hline No & Kode & \multicolumn{2}{c}{ HC } & \multicolumn{2}{c}{ CC } & \multicolumn{2}{c}{ Selisih } \\
\hline 1 & BSM & Rp & 836.649 & $\mathrm{Rp}$ & 901.316 & $\mathrm{Rp}$ & 64.667 \\
2 & BJBS & $\mathrm{Rp}$ & 37.086 & $\mathrm{Rp}$ & 39.130 & $\mathrm{Rp}$ & 2.044 \\
3 & BRIS & $\mathrm{Rp}$ & 157.473 & $\mathrm{Rp}$ & 150.111 & $\mathrm{Rp}$ & $(7.362)$ \\
4 & BMS & $\mathrm{Rp}$ & 62.270 & $\mathrm{Rp}$ & 51.638 & $\mathrm{Rp}$ & $(10.632)$ \\
5 & BSB & $\mathrm{Rp}$ & 1.525 & $\mathrm{Rp}$ & 1.506 & $\mathrm{Rp}$ & $(19)$ \\
6 & BCAS & $\mathrm{Rp}$ & 72.393 & $\mathrm{Rp}$ & 76.446 & $\mathrm{Rp}$ & 4.053 \\
7 & BNIS & $\mathrm{Rp}$ & 550.238 & $\mathrm{Rp}$ & 562.571 & $\mathrm{Rp}$ & 12.333 \\
8 & BPS & $\mathrm{Rp}$ & 21.412 & $\mathrm{Rp}$ & 25.462 & $\mathrm{Rp}$ & 4.049 \\
9 & BVS & $\mathrm{Rp}$ & 6.336 & $\mathrm{Rp}$ & 6.422 & $\mathrm{Rp}$ & 86 \\
10 & BAS & $\mathrm{Rp}$ & 540.281 & $\mathrm{Rp}$ & 555.724 & $\mathrm{Rp}$ & 15.443 \\
11 & BTPNS & $\mathrm{Rp}$ & 1.299 .019 & $\mathrm{Rp}$ & 1.347 .873 & $\mathrm{Rp}$ & 48.854 \\
12 & BNTBS & $\mathrm{Rp}$ & 53.360 & $\mathrm{Rp}$ & 52.194 & $\mathrm{Rp}$ & $(1.166)$ \\
\hline & & $\mathrm{Rp}$ & 3.638 .043 & $\mathrm{Rp}$ & 3.770 .392 & $\mathrm{Rp}$ & 132.349 \\
\hline
\end{tabular}

Sumber : Data sekunder diolah, 2020

Berdasarkan data pada Tabel 1 di atas, terlihat bahwa terdapat perbedaan nilai atau selisih (dalam rupiah) antara laba yang diperoleh dengan dasar pengukuran historical cost dengan laba yang telah mengalami penyesuaian dengan menggunakan dasar pengukuran current cost. Dari 12 sampel Bank Umum Syariah, terdapat 8 bank yang memiliki laba dengan dasar pengukuran current cost lebih tinggi dibandingkan dengan laba yang diukur dengan dasar pengukuran historical cost.

Berdasarkan pada tingkat laba yang dihasilkan, baik dengan menggunakan dasar pengukuran historical cost maupun current cost, terdapat tiga Bank Umum Syariah yang memiliki laba tertinggi, yaitu: (1) Bank Tabungan Pensiunan Nasional Syariah (BTPNS); (2) Bank Syariah Mandiri (BSM); dan (3) Bank Negara Indonesia Syariah (BNIS). Sedangkan bank 
yang memiliki tingkat laba terendah selama tahun 2018 yaitu Bank Syariah Bukopin.

Grafik 1. Perbandingan Laba Menggunakan Dasar Pengukuran Historical Cost dan Current Cost Pada Bank Umum Syariah di Indonesia Tahun 2018

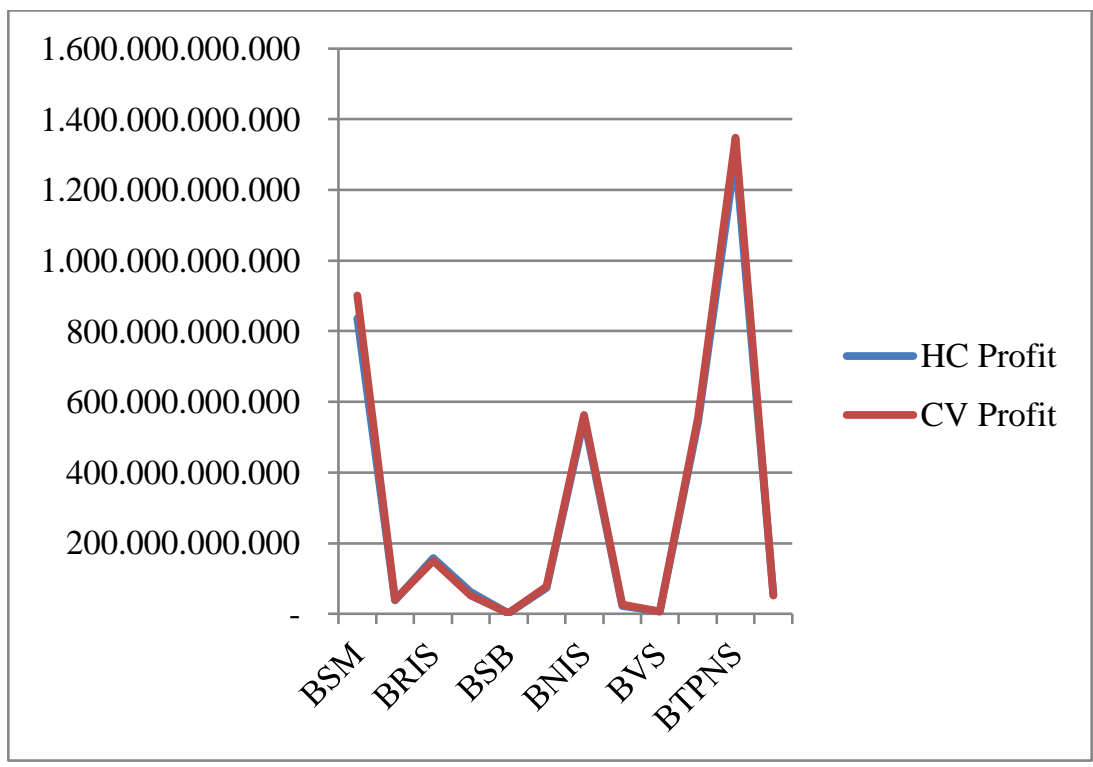

Sumber : Data sekunder diolah, 2020

Berdasarkan Tabel 1 dan Grafik 1 di atas dapat dinyatakan bahwa secara umum, total laba dari 12 bank yang dihitung dengan menggunakan dasar pengukuran current cost lebih tinggi dibandingkan dengan laba yang diperoleh dengan dasar pengukuran historical cost yang langsung diperoleh dari Laporan Laba Rugi Komprehensif bank syariah yang bersangkutan.

Perbedaan atau selisih besaran laba yang dihasilkan dengan dasar pengukuran historical cost maupun current akan berpengaruh terhadap nilai aset lancar dan ekuitas. Jika laba dengan dasar current cost lebih besar dari laba bersih dengan historical cost, maka aset lancar akan bertambah dan nilai aset/harta kena zakat juga meningkat. Karena aset lancar adalah bagian dari aset yang nantinya menjadi objek zakat, maka besaran zakat yang dibayarkan juga meningkat. Sebagai ilustrasi, total selisih laba dari12 Bank Umum Syariah dengan menggunakan dasar pengukuran historical cost dan current cost adalah Rp 132.349.056.230. Dengan demikian, potensi zakat yang hilang akibat menggunakan dasar pengukuran historical cost adalah Rp 3.308.726.406 (2,5\% x Rp 132.349.056.230).

\subsection{PENGUJIAN HIPOTESIS (PAIRED T - TEST)}

Untuk menguji hipotesis, penelitian ini menggunakan paired t-test dengan rangkaian pengujian yang akan ditampilkan pada Tabel 2 . 
Tabel 2. Uji Normalitas Data

\begin{tabular}{|c|c|c|c|}
\hline \multicolumn{4}{|c|}{ One-Sample Kolmogorov-Smirnov Test } \\
\hline & & LNHC & $\mathrm{LNCV}$ \\
\hline $\mathrm{N}$ & & 12 & 12 \\
\hline \multirow{2}{*}{ Normal Parameters ${ }^{\mathrm{a}, \mathrm{b}}$} & Mean & 25,1313 & 25,1469 \\
\hline & Std. Deviation & 2,03991 & 2,04765 \\
\hline \multirow{3}{*}{ Most Extreme Differences } & Absolute &, 155 &, 156 \\
\hline & Positive &, 108 &, 100 \\
\hline & Negative &,- 155 &,- 156 \\
\hline Test Statistic & &, 155 &, 156 \\
\hline Asymp. Sig. (2-tailed) & &, $200^{\mathrm{c}, \mathrm{d}}$ &, $200^{\mathrm{c}, \mathrm{c}}$ \\
\hline
\end{tabular}

Sumber : Data diolah, 2020

Sebelum melakukan rangkaian pengujian sampel berpasangan paired t-test, perlu dilakukan terlebih dahulu uji normalitas distribusi data pada sampel. Berdasarkan hasil pengujian normalitas data dengan menggunakan Uji Kolmoogorov Smirnov, maka diperoleh data pada penelitian ini telah terdistribusi secara normal yang dibuktikan dengan nilai signifikansi 0,200 > dari 0,05 sehingga Ho diterima yang artinya tidak ada perbedaan signifikan data - data yang telah menjadi sampel sehingga dapat disimpulkan data telah terdistribusi secara normal.

Tabel 3. Uji Rata - Rata

\begin{tabular}{cccccc}
\hline \multicolumn{5}{c}{ Paired Samples Statistics } \\
\hline \multirow{2}{*}{ Pair 1 } & Mean & N & Std. Deviation & Std. Error Mean \\
\cline { 2 - 6 } & LNHC & 25,1313 & 12 & 2,03991 &, 58887 \\
\hline & LNCV & 25,1469 & 12 & 2,04765 &, 59111 \\
\hline \multicolumn{5}{c}{ Sumber : Data diolah, 2020 }
\end{tabular}

Tahap pertama pengujian sampel berpasangan paired t-test adalah menganalisis rata - rata laba historical cost dan laba current cost. Berdasarkan informasi pada Tabel 2 di atas rata - rata laba Bank Umum Syariah menurut historical cost yang sebelumnya telah ditransformasikan ke dalam logaritma natural (LN) adalah 25,1313 sedangkan rata - rata labaBank Umum Syariah menurut current cost yang sebelumnya telah ditransformasikan ke dalam logaritma natural (LN) adalah 25,149. Berdasarkan hasil rata - rata tersebut, terlihat bahwa laba menurut current cost lebih tinggi dibandingkan dengan laba menurut historical cost meskipun perbedaannya tidak terlihat secara signifikan. 
Tabel 4. Uji Korelasi

\begin{tabular}{ccccc}
\hline \multicolumn{5}{c}{ Paired Samples Correlations } \\
\hline & $\mathrm{N}$ & Correlation & Sig. \\
\hline Pair 1 & LNHC \& LNCV & 12 &, 999 &, 000 \\
\hline
\end{tabular}

Sumber : Data diolah, 2020

Tahap kedua yaitu uji korelasi. Berdasarkan pada pengujian paired samples correlation pada Tabel 4 diatas terlihat terdapat hubungan korelasi positif di antara variabel laba yang diukur dengan historical cost dan variabel laba yang diukur dengan current cost, yang dibuktikan dengan korelasi 0,999 dengan tingkat probabilitas signifikansi $0,000<0,05$.

Tabel 5. Uji Hipotesis Paired Sampel T-Test

\begin{tabular}{|c|c|c|c|c|c|c|c|c|c|}
\hline & \multicolumn{5}{|c|}{ Paired Differences } & \multirow[b]{3}{*}{$\mathrm{t}$} & \multirow[b]{3}{*}{ df } & \multirow{3}{*}{$\begin{array}{c}\text { Sig. } \\
(2- \\
\text { tailed } \\
\quad\end{array}$} \\
\hline & & \multirow{2}{*}{$\begin{array}{c}\text { Mea } \\
\mathrm{n}\end{array}$} & \multirow{2}{*}{$\begin{array}{c}\text { Std. } \\
\text { Deviatio } \\
\text { n }\end{array}$} & \multirow{2}{*}{$\begin{array}{c}\text { Std. } \\
\text { Error } \\
\text { Mean } \\
\end{array}$} & \multicolumn{2}{|c|}{$\begin{array}{c}95 \% \text { Confidence Interval } \\
\text { of the Difference }\end{array}$} & & & \\
\hline & & & & & Lower & Upper & & & \\
\hline Pai & LNHC & & & & & & & & \\
\hline 1 & $\begin{array}{c}- \\
\text { LNC } \\
\text { V }\end{array}$ &,- 016 &, 085 & 025 &,- 069 & ,038 &,- 634 & 11 &, 539 \\
\hline
\end{tabular}

Sumber : Data sekunder yang diolah tahun 2020

Tahap terakhir yaitu pengujian hipotesis dengan menggunakan paired sampel t-test. Berdasarkan output olah data pada Tabel 5 di atas diperoleh nilai probabilitas signifikansi 0,539>0,05 yang berarti bahwa Hipotesis nol $\left(\mathrm{H}_{0}\right)$ diterima. Dengan demikian, dapat disimpulkan bahwa secara statistik dengan $\alpha=5 \%$ laba Bank Umum Syariah Tahun 2018yang dihasilkan dengan menggunakan dasar pengukuran historical cost tidak berbeda secara signifikan dengan laba yang dihasilkan dengan menggunakan dasar pengukuran current cost.

\subsection{PEMBAHASAN}

Hasil pengujian hipotesis menggunakan paired sample t-test menunjukkan bahwa Hipotesis nol $\left(\mathrm{H}_{0}\right)$ diterima, yang berarti bahwa secara statistik dengan dengan $\alpha=5 \%$ tidak terdapat perbedaan signifikan antara laba yang dihasilkan dengan dasar pengukuran historical cost dan laba yang dihasilkan dengan dasar pengukuran current cost. Current cost merupakan dasar pengukuran unsur laporan keuangan dimana biaya dari suatu aset atau liabilitas disesuaikan dengan harga saat ini yang berlaku terhadap aset yang memiliki kondisi yang sama. Harga suatu aset sangat dipengaruhi oleh kondisi fisik aset tersendiri dan tingkat permintaan dan penawaran atas aset tersebut yang nantinya akan mempengaruhi tingkat inflasi.

Perbedaan yang tidak signifikan secara statistik ini disebabkan oleh tingkat inflasi yang tidak berbeda secara signifikan setiap tahunnya sehingga menyebabkan kenaikan harga tidak terlalu signifikan berubah, bahkan terjadi 
penurunan inflasi pada tahun 2017 dan 2018. Berdasarkan Badan Pusat Statistik Indonesia pada tahun 2017, tingkat inflasi per tahun Indonesia yang diproksikan melalui Indeks Harga Konsumen (IHK) yaitu 3,61 \% dan tahun 2018 mengalami penurunan menjadi 3,13 \%. Inflasi merupakan dasar penyesuaian aset dalam pengukuran current cost. Dalam kondisi yang sesungguhnya, current cost dari aset pada periode pelaporan tidak hanya dipengaruhi oleh tingkat inflasi, tetapi berbagai faktor lainnya seperti tingkat risiko bawaan aset, kondisi lingkungan dan tingkat kompetisi pelaku pasar yang tidak dapat diperhitungkan dalam penyesuaian laba.

\section{KESIMPULAN}

Dasar pengukuran historical cost menghasilkan besaran nominal laba yang berbeda (dalam rupiah) dengan dasar pengukuran current cost. Secara umum, rata-rata laba bank Umum Syariah tahun 2018 yang dihitung dengan menggunakan dasar pengukuran current cost lebih tinggi dibandingkan dengan laba yang diperoleh dengan dasar pengukuran historical cost. Jika laba dengan dasar current cost lebih besar dari laba bersih dengan historical cost, maka aset lancar akan bertambah dan nilai aset/harta kena zakat juga meningkat. Hasil uji statistik paired t-test menunjukkan bahwa secara statistik dengan $\alpha=5 \%$ laba 12 Bank Umum Syariah Tahun 2018 yang dihasilkan dengan menggunakan dasar pengukuran historical cost tidak berbeda secara signifikan dengan laba yang dihasilkan dengan menggunakan dasar pengukuran current cost (prob. 0,539>0,05). Dengan demikian, $H_{a}$ ditolak.

Mengingat model pengukuran current cost dan historical cost dapat menghasilkan besaran laba dan besaran zakat yang berbeda serta dasar pengukuran current cost berdasarkan pendapat ahli fikih selaras dengan prinsip syariah, maka Dewan Standar Akuntansi Syariah (DSAS) dapat mempertimbangkan untuk mengatur secara khusus dasar pengukuran yang sebaiknya digunakan untuk menghitung dan melaporkan kewajiban zakat perusahaan. Bank syariah sebagai entitas syariah yang berkewajiban membayar zakat atas bisnisnya maupun lembaga penghimpun zakat seperti Badan Amil Zakat dan Lembaga Amil Zakat juga seharusnya memiliki pemahaman yang memadai tentang dasar pengenaan zakat ketika menghitung zakat perusahaan.

Peneliti selanjutnya dapat mempertimbangkan untuk menggunakan sampel entitas syariah yang tidak hanya berasal dari sektor perbankan, tetapi dari berbagai sektor industri sehingga dapat diperbandingkan antara satu sektor industri dengan industri yang lain. Peneliti selanjutnya diharapkan dapat menggunakan alternatif metode lainnya yang diperkenankan sebagai dasar perhitungan zakat perusahaan sehingga dapat memperkaya literatur tentang zakat perusahaan. 


\section{DAFTAR PUSTAKA}

Ahmed, E. R., Bin Aiffin, K. H., Yousif Alabdullah, T. T., \& Zuqebah, A. (2016). Zakat and accounting valuation model. Journal of Reviews on Global Economics. https://doi.org/10.6000/1929-7092.2016.05.02

Awang, R., \& Mokhtar, M. Z. (2012). Comparative Analysis of Current Values and Historical cost in Business Zakat Assessment: An Evidence from Malaysia. International Journal of Business and Social Science.

Dewan Standar Akuntansi Syariah IAI. (2016). Standar Akuntansi Keuangan Syariah. Ikatan Akuntan Indonesia (Cetakan Pe). Jakarta: Ikatan Akuntan Indonesia.

Farhan, A., \& Triyuwono, I. (2012). Metode Perhitungan Zakat Perusahaan pada CV. Minakjinggo. Jurnal Ilmiah Mahasiswa FEB, 1(2).

Gambling, T., \& Karim, R. A. A. (1991). Bussinees and Accounting Ethics in Islam. London: Mansell Publisher.

Ghozali, I. (2006). Ghozali, Imam. 2006. Aplikasi Analisis Multivariate dengan Program SPSS. Semarang: Badan Penerbit UNDIP. In Analisis Multivariate dengan Program SPSS.

Harahap, S. S. (2011). Teori Akuntansi Edisi Revisi 2011. Rajawali Pers. https://doi.org/www.rajagrafindo.com

Hartono, A. (2016). DEVIASI ATAS RELEVANSI KONSEP LAPORAN KEUANGAN HISTORICAL COST DAN CURRENT COST DENGAN KONSEP AKUNTANSI SYARIAH TERHADAP PENGAMBILAN KEPUTUSAN. Ekuilibrium : Jurnal Ilmiah Bidang Ilmu Ekonomi. https://doi.org/10.24269/ekuilibrium.v10i1.43

Mirza, M., \& Baydoun, N. (2000). Accounting policy choice in an interestfree environment. Accounting, Commerce and Finance: The Islamic Perspective Journal.

Mufraini, M. A. (2006). Akuntansi dan manajemen zakat. Prenadamedia Group.

Muhammad. (2003). Penilaian Asset Dalam Akuntansi Syari'ah. Penilaian Aset Dalam Akuntansi Syariah.

Muhammad, P. A. S. (2005). edisi 2. Jakarta: Salem-Ba Empat.

Pratiwi, M., \& Siswantoro, D. (2018). Fair Value in the Islamic Perspective: Jakarta Islamic Index (JII) Companiesr Cases. https://doi.org/10.2991/iac-17.2018.47

Qardhawi, Y. (2004). Hukum Zakat (terjemahan dari buku Fiqhuz Zakat). Jakarta: Pustaka Litera AntarNusa.

Sidik, G. K., \& Djazuli, A. (2010). Relevansi Current Value Accounting Sebagai Metode dalam Menilai Harta Zakat Perusahaan. Jurnal 
Akuntansi Islam, 01 No. 1(Juni 2010), 139-164.

Suwardjono. (2011). Teori Akuntansi Perekayasaan Pelaporan Keuangan edisi ketiga cetakan kelima. Teori Akuntansi Perekayasaan Laporan Keuangan (edisi ketiga).

Syafei, A. W. (2008). Mari Dukung PSAK Zakat Perusahaan. Republika.

Triyuwono, I. (2012). Akuntansi Syariah: Perspektif, Metodologi, dan Teori Edisi. Jakarta: PT. Raja Grafindo Persada.

Wasilah, S. N. D. (2013). Akuntansi Syariah Di Indonesia Edisi 3. Jakarta: Salemba Empat.

YAYA, R. (2003). OBJECTIVES AND CHARACTERISTICS OF ISLAMIC ACCOUNTING: Perceptions of Muslim Accounting Academicians IN YOGYAKARTA, INDONESIA Rizal Yaya. In International Conference Pan Pacific. 